\title{
ANALISIS IMPLEMENTASI MUTU PEMBELAJARAN DI SMP MUHAMMADIYAH 3 BANDAR LAMPUNG
}

\author{
Taufik ikbal, Nurhadi kusuma, Eri Purwanti \\ Jl. Raya Wonokriyo Gadingrejo Pringsewu \\ Email: stitpringsewu@gmail.com
}

\begin{abstract}
This study is a study using Roesman's theory approach in the book of learning models to develop teacher professionalism. To measure the extent to which the implementation of learning is considered qualified.

From the results of observations and interviews and reviewed from the theory of learning models Roesman then obtained: 1. Bahwasannya in the planning phase of teacher learning in smp muhamadiyah 3 bandar still exist that have not yet compiled syllabus and RPP. 2. In the implementation stage of learning, teachers still have not applied apersepsi in starting learning and have not used props, 3. There are sub indicators in syllabus or indikaator that have not been implemented in each learning subject, 4. At the time of closing the learning and giving assessment of the teacher have been seeking the fulfillment of assessment in accordance with PP Education Minister No 23 of 2016.
\end{abstract}

\begin{abstract}
Abstrak
Penelitian ini merupakan kajian yang menggunakan analisis pendekatan teori Roesman dalam buku model - model pembelajaran mengembangkan profesionalisme guru. Untuk mengukur sejauh mana implementasi pembelajaran yang dianggap bermutu.

Dari hasil pengamatan dan wawancara serta ditinjau dari teori Model-Model Pembelajaran Roesman maka didapat :1. Bahwasannya dalam tahap perencanaan pembelajaran guru di smp muhamadiyah 3 bandar lampung masih ada yang belum menyusun Silabus dan RPP. 2. Pada tahap pelaksanaan pembelajaran guru masih banyak belum menerapkan apersepsi dalam memulai pembelajaran serta belum menggunakan alat peraga, 3. Adanya sub indikator dalaam silabus maupun indikaator yang belum dilaksanakan pada tiap mata pelaajaran, 4. Pada saat menutup pembelajaran serta memberikan penilaian guru sudah mengupayakan terpenuhinya penilaian sesuai dengan PP Mendikbud Nomor 23 Tahun 2016.
\end{abstract}

Kata kunci : Mutu, pembelajaran 


\section{A. PENDAhuluan}

Kualitas pendidikan didalam sebuah lembaga pendidikan sangatlah diperlukan, dengan kualitas pendidikan yang baik dapat menciptakan sumber daya manusia yang memiliki keahlian dan keterampilan untuk memenuhi tujuan pendidikan Indonesia.

Namun yang menjadi penghambat kaitannya dalam peningkatan mutu pendidikan di Indonesia yaitu masih rendahnya mutu pendidikan yang ada di sebuah lembaga pendidikan. Rendahnya mutu pendidikan inilah yang menjadi penyebab terhambatnya penyediaan sumber daya manusia yang memiliki keahlian dan keterampilan untuk memenuhi kebutuhan tujuan pendidikan pendidikan di Indonesia, rendahnya mutu pendidikan ini di sebabkan oleh kualitas guru yang kurang profesional dan berkompetensi, sarana dan prasarana sebagai alat penunjang pendidikan yang kurang lengkap dan memadai, serta lingkungan yang kurang mendukung yang menyebabkan rendahnya prestasi para peserta didik.

Praktik manajemen mutu pendidikan tidak selamanya berjalan mulus dan lancar, kadangkadang muncul berbagai kendala dalam mewujudkan mutu pendidikan sebagaimana yang diharapkan. Penyebab kegagalan mencapai mutu pendidikan yaitu berkenaan dengan rendahnya kemampuan mendesain kurikulum, sistem dan prosedur kerja tidak cocok, pengaturan waktu tidak mencukupi, kurangnya sumber, pengembangan staf yang tidak memadai dan lingkungan kerja tidak menunjang.

Mutu pembelajaran merupakan gambaran kualitas pembelajaran secara utuh dari proses dan hasil pembelajaran sesuai dengan yang diharapkan. Proses dan hasil pembelajaran meliputi perencanaan proses pembelajaran, pelaksanaan proses pembelajaran, penilaian hasil pembelajaran, dan pengawasan proses pembelajaran untuk terlaksananya proses pembelajaran yang efektif dan efisien. (Roesman :2012;4)

Teori di atas penulis jadikan indikator mutu pembelajaran. Berdasarkan hasil prasurvey yang peneliti lakukan, pada perencanaan pembelajaran yang ada di SMP Muhammadiyah 3 Bandar Lampung sudah terlaksana, perencanaan pembelajaran yang diterapkan sudah sesuai dengan indikator yang peneliti gunakan. Pada Pelaksanan pembelajaran belum terlaksana di karenakan masih terdapat beberapa guru dalam kegiatan pendahuluan, inti dan penutup belum melaksanakan nya dengan maksimal sesuai inikator yang peneliti gunakan. Pada penilaian hasil pembelajaran yang peneliti lakukan di SMP
Muhammadiyah 3 Bandar Lampung sudah terlaksana dengan sudah terpenuhi sub indikator yang menjadi acuan bagi penulis dalam melakukan pra survei.

Selain itu SMP Muhammadiyah 3 Bandar Lampung yang berdiri sejak tahun 1973 memiliki ciri khas yang menjadi unggulan yaitu seluruh aktivitas dimulai dari pagi hari sampai dengan siang hari. Dimulai dari pukul 07.15 masuk kelas dengan diawali kegiatan tadarus, istirahat pertama sholat dhuha pada pukul 09.40-10.20 lalu masuk kembali kekelas, dan pukul 11.40-12.20 istirahat sholat dzuhur kemudian dimulai kembali sampai dengan selesai kegiatan belajar mengajar pada pukul 14.00 WIB.

Dari data pra survey, maka penulis tertarik untuk melakukan analisis implementasi manajem en mutu pembelajaran di SMP Muhammadiyah 3 Bandar Lampung.

\section{B. TUJUAN PENELITIAN}

Dalam setiap penelitian maupun tindakan memiliki tujuan, dan yang menjadi tujuan penelitian ini adalah :

1. Ingin mengetahui sejauh mana implementasi mutu pembelajaran yanag dilakukan guru di SMP Muhamadiah 3 Bandar Lampung

2. Melakukan analisis kesesuaian antara konsep dan teori Roesman dan implementasi nya di lembaga pendidikan.

\section{METODE PENELITIAN}

Jenis penelitian ini adalah deskriptif kualitatif yaitu penelitian yang bersifat menggambarkan, menuturkan dan menafsirkan data yang ada dan menghasilkan data deskriptif berupa kata-kata tulisan/lisan dari orang-orang dan prilaku yang dapat diamati dan data tersebut bersifat pernyataan.

Teknik pengumpulan data dengan cara observasi, wawancara, dan dokumentasi. Data yang di peroleh selama penelitian di analisis dengan langkah-langkah reduksi data, penyajian data, dan penarikan kesimpulan. Sedangkan uji keabsahan data dilakukan dengan ketekunan dan pengamatan dan triangulasi. Triangulasi yang di gunakan dalam penelitian ini adalah triangulasi teknik.

\section{PEMBAHASAN}

Analisis Implementasi Mutu Pembelajaran di SMP Muhammadiyah 3 Bandar Lampung

Dalam penelitian, penulis menggunakan data penelitian bersifat kualitatif, data yang ditampilkan bersifat narasi dan dijabarkan dalam bentuk pertanyaan-pertanyaan yang peneliti 
berikan dalam wawancara yang di adakan dari tanggal 12 April - 12 Mei 2017.

Berikut ini penulis paparkan hasil wawancara dengan kepala sekolah dan guru mengenai Impelementasi manajemen mutu Pembelajaran yang mengacu pada teori Rusman diatas sebagai berikut:

\section{Perencanaan Pembelajaran}

Berdasarkan wawancara yang peneliti lakukan dengan dewan guru di SMP Muhammadiyah 3 Bandar Lampung, sekolah tersebut selalu mempersiapkan perencanaan pembelajaran dengan baik, hal ini sesuai pernyataan saat mewawancarai guru SMP Muhammadiyah 3 Bandar lampung sebagai berikut:

"Ya, tentu saja dewan guru di SMP Muhammadiyah 3 bandar lampung kami selalu mempersiapkan perangkat pembelajaran, saya selalu membuat RPP, dan Silabus. agar nanti ketika pelaksanaan pembelajaran bisa melaksanakan nya dengan maksimal, karena itu adalah salah satu dari perencanaan pembelajaran. Kami juga mempersiapkan alat peraga dan media yang relevan. Sehingga murid bisa lebih memahami tentang materi yang di sampaikan. (Tri Handayani Guru SMP Muhammadiyah 3 Bandar Lampung, wawancara 08 Mei 2017).

Hasil wawancara dengan guru tersebut di perkuat dengan hasil wawancara yang dilakukan dengan Kepala Sekolah SMP Muhammadiyah 3 Bandar Lampung, sebagai berikut:

"Ya, memang benar dalam perencanaan pembelajaran guru-guru yang ada di SMP Muhammadiyah 3 Bandar Lampug selalu mempersiapkan perangkat pembelajaran dengan baik, mereka selalu membuat RPP, dan Silabus serta perangkat pembelajaran yanglainnya. (Wahdiyana, Kepala sekolah SMP Muhammadiyah 3 Bandar Lampung, wawancara 09 Mei 2017).

Akan tetapi ketika peneliti melakukan waawancara dan menanyakan kepada salah satu guru yang baru mengajar di SMP Muhammadiyah 3 Bandar lampung yaitu guru mata pelajaran bahasa Arab apakah sudah membuat RPP dan Silabus, guru tersebut mengakui bahwasanya dirinya belum membuat perangkat pembelajaran tersebut. Alasannya adalah dikarenakan belum sempat dan masih baru mengajar belum genap satu semester. (Suci setianingsih Guru SMP Muhammadiyah 3 Bandar Lampung, wawancara 08 Mei 2017).

Permasalahan pun peneliti temukan ketika melakukan observasi. Hasil observasi yang dilakukan ternyata masih terdapat guru yang belum mempersiapkan alat peraga atau media belajar yang relevan, hal itu dapat dilihat dari dokumentasi yang peneliti dapatkan.

Hasil observasi tersebut di perkuat dengan hasil wawancara yang peneliti lakukan dengan siswa SMP Muhammadiyah 3 Bandar Lampung.

"Pada saat guru mengajar sering sekali guru tidak menggunakan alat peraga dan media belajar, hanya pelajaran tertentu saja yang menggunakan media dan alat peraga. Banyak guru nya nggk bawa apa-apa, Cuma bawa buku paket aja".'. (Budi Santoso Peserta Didik SMP Muhammadiyah 3 Bandar Lampung, wawancara 09 Mei 2017)

Berdasarkan hasil wawacara, observasi, dan diperkuat dengan dokumentasi serta teori diatas, maka peneliti dapat menganalisis bahwa perencanaan pembelajaran yang ada di SMP Muhammadiyah 3 Bandar Lampung sudah terlaksana dengan baik karena sudah memenuhi indikator diatas. Akan tetapi ada juga yang belum terlaksana di karenakan masih terdapat guru yang belum membuat RPP dan Silabus serta terkadang belum menggunakan alat peraga dan media pembelajaran.

\section{Pelaksanaan Pembelajaran}

a. Persyaratan Pelaksanan Pembelajaran

Kepala sekolah menjelaskan bahwasanya persyaratan pelaksanaan pembelajaran di SMP Muhammadiyah 3 Bandar Lampung dalam hal (Rombel) rombongan belajar masih kurang karena keterbatasan ruangan dengan jumlah siswa yang tidak seimbang, namun kelebihan kapasitas itu tidak mengganggu kegiatan belajar mengajar.

Pembelajaran di SMP muhammadiyah 3 bandar lampung untuk rombongan belajarnya masih belum sesuai antara jumlah murid dan jumlah ruangan, karena mengingat jumlah ruangan yang terbatas.Akan tetapi jumlah siswa dan kapasitas ruangan tidak membuat kegiatan belajar mengajar jadi terhambat. Kegiatan belajar mengajar tetap nyaman dan kondusif. (Wahdiyana, Kepala sekolah SMP Muhammadiy ah 3 Bandar Lampung, wawancara 09 Mei 2017)

Berdasarkan hasil wawacara, observasi, dan diperkuat dengan teori diatas, maka peneliti dapat menganalisis bahwa dalam hal pengelolaan kelas guru sudah melaksanakannya dengan baik, guru sudah mengatur tempat duduk sesuai dengan karakteristik peserta didik dan mata pelajaran, volume dan intonasi suara guru dalam proses pembelajaran juga dapat didengar dengan baik oleh peserta didik, tutur kata guru santun dan dapat dimengerti oleh peserta didik sesuai indikator dari teori Rusman di atas. 
b. Pelaksanaan Pembelajaran

a). Kegiatan Pendahuluan

Hasil wawancara yang peneliti lakukan dengan siswa SMP Muhammadiyah 3 Bandar Lampung.

"Ya, memang benar sebelum pelajaran dimulai guru selalu mengaitkan pelajaran yang akan di bahas dengan pelajaran yang sudah dipelajari. Terkadang guru juga menanyakan pekerjaan rumah (pr).( Dewi Susanti siswa SMP Muhammadiyah 3 Bandar Lampung, wawancara 09 Mei 2017)

Akan tetapi hal ini bertolak belakang dari hasil observasi yang peneliti lakukan, bahwasanya ternyata masih terdapat guru dalam memulai pelajaran tidak melakukan pendahuluan, tidak mengaitkan pelajaran sebelumnya dengan pelajaran yang akan di bahas.

Berdasarkan hasil wawacara, observasi, dan diperkuat dengan teori diatas, maka peneliti dapat menganalisis bahwa dalam kegiatan pendahuluan guru sudah melaksanakannya dengan baik, akan tetapi pada beberapa mata pelajaran menurut hasil observasi yang didapatkan oleh peneliti ternyata masih terdapat guru yang belum melaksanakan kegiatan pendahuluan ketika memulai pembelajaran.

b) Kegiatan Inti

Hasil wawancara yang peneliti lakukan dengan guru mata pelajaran Al-islam adalah sebagai berikut:

'Ketika melaksanakan proses kegiatan belajar mengajar memang sudah seharusnya smua materi yang disampaikan sesuai dengan RPP, materi yang di sampaikan harus jelas, harus memiliki wawasan yang luas, keterampilan, inovasi, dan kreativitas itu smua harus di kuasai dan di terapkan dalam kegiatan belajar mengajar."( Wahyu Sujayanto Guru SMP Muhammadiyah 3 Bandar Lampung, wawancara 08 Mei 2017)

Hasil wawancara dengan guru tersebut tidak relevan dengan hasil wawancara yang dilakukan kepada peserta didik, yaitu sebagai berikut:

"Pada saat belajar dikelas materi yang di dampaikan oleh guru mata pelajaran Al-Islam kami susah memahami apa yang disampaikan karena cara ngajarnya galak dan gitu-gitu aja. Sering nya hafalan terus, dan ketika waktu istirahat kami pelajaran kami belum selesai. "(Dwi Purwanti Guru SMP Muhammadi yah 3 Bandar Lampung, wawancara 08 Mei 2017)

Hasil wawancara dengan siswa tersebut di perkuat dengan hasil observasi yang peneliliti lakukan, bahwasanya ketika guru melaksanakan kegiatan pembelajaran peneliti guru tersebut belum maksimal menguasai materi, sehingga siswa kurang memahami apa yang disampaikan. Suasana kelas pun menegangkan, tidak adanya inovasi, dalam kreatifitas dalam proses pembelajaran serta pengunaan alokasi waktu yang kurang efektif.

Berdasarkan hasil wawacara, observasi, dan diperkuat dengan teori diatas, maka peneliti dapat menganalisis bahwa dalam kegiatan inti untuk mata pelajaran Al-Islam masih belum terlaksana dengan baik, hal ini di lihat dari hasil wawancara dengan siswa dan hasil observasi yang dilakukan oleh peneliti meyebutkan bahwa ada beberapa sub indikor yang tidak dilaksanakan sehingga hal itu membuat kegiatan belajar mengajar menjadi kurang efektif dan efisien.

c) Kegiatan Penutup

Hal ini sesuai pernyataan saat mewawancarai guru SMP Muhammadiyah 3 Bandar lampung sebagai berikut:

"Tentu, ketika menutup pelajaran saya menyimpulkan kegiatan belajar mengajar atau materi yang telah disampaikan, melakukan evaluasi serta melakukan pengayan dan pemdalaman." (Dwi Purwanti Guru SMP Muhammadiyah 3 Bandar Lampung, wawancara 08 Mei 2017)

Hasil wawancara dengan guru dan siswa tersebut juga diperkuat dengan hasil observasi yang dilakukan peneliti, bahwasanya kegiatan penutup dilakukan oleh guru dengan memberikan rangkuman atau kesimpulan, umpan baik serta pendalaman.

Berdasarkan teori, hasil wawancara dan diperkuat dengan hasil observasi di atas maka peneliti dapat menganalisis bahwa dalam kegiatan penutup sudah terlaksana dengan baik. Hal itu di dikarenakan dalam kegiatan penutup guru memberikan rangkuman atau kesimpulan, umpan baik, serta memberikan tugas yang sifatnya memberikan pengayaan dan pendalaman.

\section{Penilaian Hasil Pembelajaran}

Ketika peneliti melakukan wawancara dengan kepala sekolah terkait penilaian, sebagai berikut:

"Penilaian dilakukan untuk mengetahui sejau mana pencapaian kompetensi lulusan, penguasaan pengetahuan, serta untuk memantau dan mengevaluasi, kemajuan belajar, dan perbaikan hasil belajar, suswa secara berkesinambungan. Namun hal yang harus diperhtikan penilaian itu hendaknya berdasarkan RPP dan Silabus.( Wahdiyana, Kepala sekolah SMP Muhammadiyah 3 Bandar Lampung, wawancara 09 Mei 2017).

Hasil wawancara dengan kepala sekolah tersebut diperkuat dengan hasil wawancara yang peneliti lakukan dengan guru SMP 
Muhammadiyah 3 Bandar Lampung, sebagai berikut:

"Banyak cara yang dilakukan dalam penilaian kepada siswa, yaitu dengan cara memberikan tugas, baik tugas rumah ataupun dikelas, pengamatan, ulangan, ujian sekolah atau penilaian yang lainnya bila diperlukan, yang pasti penilalain kompetensi maupun sikap dan akhlak karena disini kan sekolah berbasis Islam.(Erwin Junaidi Guru SMP Muhammadiyah 3 Bandar Lampung, wawancara 08 Mei 2017)

Hasil wawancara dengan guru tersebut juga diperkuat dengan hasil wawancara kapada siswa, sebagai berikut:

"ya, setiap guru memberikan tugas pekerjaan rumah atau dikelas pasti hasil tugas kami tersebut selalu dikumpul untuk diberi penilaian. Kadang juga dengan kerapihan dinilai, beliau ada salah satu buku yang berisi tentang nilai kami. (Dewi Susanti siswa SMP Muhammadiyah 3 Bandar Lampung, wawancara 09 Mei 2017)

Hasil wawancara dengan guru dan siswa tersebut relevan dengan Peraturan Menti Pendidikan dan Kebudayan Republik Indonesia Nomor 23 Tuahun 2016 Tentang Standar Penilaian Pendidikan pada bab V Bab bentuk Penilaian pasal 6 dan 7 .

\section{E. PENUTUP}

\section{Kesimpulan}

Berdasarkan hasil penelitian dan pembahasan penelitian tentang Implementasi Manajemen Mutu Pembelajaran di SMP Muhammadiyah 3 Bandar Lampung, baik melalui wawancara, observasi, dan dokumentasi. Maka penulis simpulkan sebagai berikut :

\section{Perencanan Pembelajaran}

Perencanaan pembelajaran yang ada di SMP Muhammadiyah 3 Bandar Lampung sudah terlaksana dengan baik hal ini dikarenakan perencanan pembelajaran yang di terapkan sudah sesuai dengan indikator dalam teori Rusman yang peneliti gunakan. Akan tetapi ada juga yang belum terlaksana di karenakan masih terdapat guru yang belum membuat RPP dan Silabus serta terkadang belum menggunakan alat peraga dan media pembelajaran.

\section{Pelaksanan Pembelajaran}

a) Kegiatan Pendahuluan

Dalam kegiatan pendahuluan guru sudah melaksanakannya dengan baik, akan tetapi pada beberapa mata pelajaran menurut hasil observasi yang didapatkan oleh peneliti ternyata masih terdapat guru yang belum melaksanakan kegiatan pendahuluan ketika memulai pembelajaran.

b) Kegiatan Inti
Dalam kegiatan inti untuk mata pelajaran Al-Islam masih belum terlaksana dengan baik, hal ini di lihat dari hasil wawancara dengan siswa dan hasil observasi yang dilakukan oleh peneliti meyebutkan bahwa ada beberapa sub indikor yang tidak dilaksanakan sehingga hal itu membuat kegiatan belajar mengajar menjadi kurang efektif dan efisien.

c) Kegiatan Penutup

Dalam kegiatan penutup sudah terlaksana dengan baik. Hal itu di dikarenakan dalam kegiatan penutup guru memberikan rangkuman atau kesimpulan, umpan baik serta memberikan tugas yang sifatnya memberikan pengayaan dan pendalaman.

\section{Penilaian Hasil Pembelajaran}

Dalam penilaian hasil pembelajaran sudah terlaksana dengan baik, penilaian yang dilakukan sudah memenuhi indikator mutu pembelajaran dari teori rusman maupun dari Peraturan Menti Pendidikan dan Kebudayan Republik Indonesia Nomor 23 Tahun 2016 Tentang Standar Penilaian Pendidikan.

\section{SARAN}

Berdasarkan hasil analisis dan kesimpulan yang disajikan, maka penulis mencoba mengemukakan beberapa saran sebagai berikut :

\section{Perencanan Pembelajaran}

Hendaknya bagi guru selalu mempersiapkan perangkat pembelajaran yang meliputi Silabus dan Rencana Pelaksanaan Pembelajaran (RPP) yang memuat identitas mata pelajaran,Standar Kompetensi (SK), Kompetensi Dasar (KD), indikator pencapaian kompetensi, tujuan pembelajaran, materi ajar, alokasi waktu, metode pembelajaran, kegiatan pembelajaran, penilaian hasil belajar, dan sumber belajar. Sehingga ketika akan melaksanakan pembelajaran guru sudah siap dang bisa menyampaikan materi dengan maksimal.

\section{Pelaksanan Pembelajaran}

a). Kegiatan Pendahuluan

Ketika akan memulai pelajaran hendaknya guru memperhatikan sikap dan tempat duduk siswa, menjelaskan pentingnya materi pelajaran yang akan dipelajari, serta melakukan apresiasi (mengaitkan materi yang disajikan dengan materi yang telah dipelajari sehingga terjadi kesinambungan).

b). Kegiatan inti

Dalam pelaksanaan pembelajaran sebaiknya kegiatan pembelajaran dilakukan secara interaktif, inspiratif, menyenangkan, menantang, memotivasi peserta didik untuk berpartisipasi aktif, serta memberikan ruang yang cukup bagi prakarasa, kreativitas, dan kemandirian sesuai 
dengan bakat, minat, dan perkembangan fisik, serta psikologis peserta didik.

c). Kegiatan Penutup

Dalam menutup kegiatan pembelajaran

yang dilakukan hendaknya guru ketika mengakhiri aktivitas pembelajaran dengan memberikan rangkuman atau kesimpulan, penilaian dan refleksi, umpan balik, serta tindak lanjut agar siswa bisa lebih memahami materi yang telah disampaikan.

\section{Penilaian Hasil Pembelajaran}

Hendak nya ketika guru melakukan penilaian Prosedur dan instrumen penilaian proses dan hasil belajar disesuaikan dengan indikator pencapaian kompetensi dan mengacu pada Standar Penilaian.

\section{DAFTAR PUSTAKA}

Anisari, A., Purwanti, E., \& Masrur, M. (2017). Strategi Kepala Sekolah Dalam Meningkatkan Mutu Pembelajaran Di Smp Nurul Islam Kelurahan Garuntang Kecamatan Bumi Waras Kota Bandar Lampung. Jurnal Manajemen Pendidikan Islam Al-Idarah, 1(1), 1-9.

Hadis dan Nurhayati. 2010, Manajemen Mutu Pendidikan, Bandung: Alfabeta

Kusuma, N., \& Purwanti, E. (2017). Pengaruh Kompetensi Pedagogik Dan Manajemen Pembelajaran Terhadap Penjaminan Mutu Pada Universitas Sang Bumi Ruwa Jurai Lampung. Indonesian Journal Of Educational Counseling, 1(2), 209-226.

Rousman. 2012, Model-model Pembelajaran Mengembangkan Profesionalisme guru, Jakarta: PT Rajagrafindo Persada

Suaedi Hammado Tantu. 2016, Pembelajaran Pendidikan Lingkungan Hidup, Bogor: IPB Press

UU SISDIKNAS (UU RI No.20 Th. 2003). 2013 Jakarta: Sinar Grafika, 